DOI: https://doi.org/10.24867/10DS03Smiljanic

\title{
ANALIZA PREVOZNIH TROŠKOVA U TRANSPORTU OPASNIH MATERIJA PRIMENOM STATISTIČKIH MODELA
}

\section{ANALYSIS OF TRANSPORT COSTS IN THE TRANSPORT OF DANGEROUS GOODS USING STATISTICAL MODELS}

\author{
Dragan Smiljanić, Gordan Stojić, Fakultet tehničkih nauka, Novi Sad
}

\begin{abstract}
Oblast - SAOBRAĆAJ
Kratak sadržaj - Prevozni troškovi u transportu opasnih materija u drumskom saobraćaju u radu izračunati su na osnovu opšte prihvaćenih metoda $i$ dostupnih podataka. Takođe, proračuniti su i troškovi ukoliko bi se transport opasnih materija realizovao železničkim saobraćajem na onim relacijama $i$ za one količine za koje bi bio celishodan. Za utvrđivanje količine opasnih materija po relacijama prevoza korišćene su odgovarajuće statističke metode.
\end{abstract}

Ključne reči: Troškovi transporta, opasne materije, raspodele, supstitucija

Abstract - Transport costs in the transport of dangerous goods in road traffic in the work of computers are based on generally accepted methods and available data. Also, the costs were calculated if the transport would take place by rail on those routes and for one number for which it would be expedient. It was used with appropriate statistical methods to determine some dangerous goods by transport routes.

Keywords: Transport costs, dangerous goods, distribution, substitution

\section{UVOD}

Opasne otpadne materije su otpadne materije koje sadrže hemijske elemente i njihova jedinjenja, odnosno elemente koje svojim osobinama i hemijskim reakcijama ugrožavaju životnu sredinu, život i zdravlje ljudi. Otpad je zapravo svaka materija ili predmet zadržan u listi kategorija otpada, koji vlasnik odbacuje. Može nastati tokom ekstrakcije sirovina, prerade sirovina $u$ poluproizvode $i$ gotove proizvode, potrošnje gotovih proizvoda i drugih ljudskih aktivnosti. Opasne materije jesu sve materije, stvari, roba, tereti, proizvodi i supstance koje na bilo koji način mogu štetno uticati na okolinu [1].

Tema i cilj ovog master rada jesu procena troškova prevoza u drumskom saobraćaju između određenih mesta otpreme i dopreme, i potencijalna realizacija prevoza železničkim saobraćajem kako bi se smanjili troškovi prevoza [2].

\section{NAPOMENA:}

Ovaj rad proistekao je iz master rada čiji mentor je bio dr Gordan Stojić , van. prof.

\section{TROŠKOVI EKSPLOATACIJE VOZILA U DRUMSKOM SAOBRAĆAJU}

U svim granama saobraćaja pa i u drumskom saobraćaju transportni troškovi predstavljaju najvažniji uopšteni pokazatelj rezultata poslovanja. Finansijski rezultat poslovanja autotransportnih organizacija predstavlja skup odnosa koji pokazuje formiranje i trošenje novčanih sredstava u autotransportnoj proizvodnji.

Cena prevoza predstavlja jedan od važnijih ekonomski pokazatelja za ocenjivanje kvaliteta rada autotransportne organizacije i data je novčanim oblikom troškova proizvodnje autotransportne organizacije za izvršenje jedinice transportnog rada.

2.1. Uticaj inteziteta eksploatacije vozila na formiranje troškova i promenu troškova pređenog kilometra vozila

U Srbiji, je u skladu sa Zakonom o sistemu društvene kontrole cena, u okviru Opšteg udruženja saobraćaja donešen Jedinstveni cenovnik (tarifa) prevoznih usluga $u$ javnom drumskom transportu na području zemlje.

Ova tarifa služi kao osnova drumskim prevoznicima za izradu sopstvenog cenovnika prevoznih usluga u javnom drumskom prevozu, pri čijoj izradi društva moraju voditi računa i o odredbama Zakona o ugovorima o prevozu $\mathrm{u}$ drumskom prevozu, Zakona o amortizaciji po vrstama vozila i dr. U drumskom transportu tarife donose transportna privredna društva ili udruženja (Tabela 1.) i retko koje su javno dostupne. Ne postoje jedinstvene tarife za drumski transport u unutrašnjem saobraćaju [3].

\section{UTVRĐIVANjE PREVOZNIH TROŠKOVA U \\ ŽELEZNIČKOM SAOBRAĆAJU}

Železničke tarife predstavljaju skup zakonskih i tarifskih odredaba kojima se regulišu uslovi i cene prevoza putnika i robe. Tarifska načela za obrazovanje cena baziraju se na tarifskim teorijama pri čemu treba da se obezbedi interes države i železnice. Tarifski sistem predstavnja skup tarifskih propisa i tarifskih načela na kojima je izrađen. [4].

Tarifa za prevoz robe na Železnicama Srbije (ŽS) sastoji se iz 7 delova:

1. uslovi prevoza i računanje prevoznine

2. klasifikacija robe

3. imenik žel. stanica Srbije

4. daljinar za prevoz robe na ŽS

5. putokaz

6. cenovnik žel. usluga

6a. naknada za industrijske i posebne koloseke i manipulativne pruge

7. tranzitna tarifa [5]. 
Tabela 1. Tarife u drumskom transportu

\begin{tabular}{|c|l|c|c|}
\hline $\begin{array}{c}\text { Grupe } \\
\text { troškova }\end{array}$ & \multicolumn{1}{|c|}{$\begin{array}{c}\text { Vrste troškova u drumskom teretnom } \\
\text { transportu }\end{array}$} & $\begin{array}{c}\text { Učešć grupa u } \\
\text { ukupnim troškovima } \\
\text { bez PDV-a }\end{array}$ & $\begin{array}{c}\text { Finansijski iznos } \\
\text { troškova po kilometru } \\
\text { u RSD }\end{array}$ \\
\hline 1 & Gorivo & $34,05 \%$ & 93,52 \\
\hline 2 & Održavanje, mazivo, delovi i materijali & $3,96 \%$ & 10,88 \\
\hline 3 & Autogume & $3,77 \%$ & 10,36 \\
\hline 4 & Amortizacija & $14,47 \%$ & 39,74 \\
\hline 5 & Bruto zarade zaposlenih & $21,17 \%$ & 58,16 \\
\hline 6 & Putarine i ostali putni troškovi & $1,70 \%$ & 4,66 \\
\hline 7 & Osiguranje i registracija vozila & $2,34 \%$ & 6,42 \\
\hline 8 & Putni troškovi & $3,20 \%$ & 8,8 \\
\hline 9 & Reklama, propaganda i reprezentacija & $0,64 \%$ & 1,76 \\
\hline 10 & Platni promet i kamate za poslovanje & $1,70 \%$ & 4,66 \\
\hline 11 & Kanc. materijal i sitan inventar & $1,85 \%$ & 5,08 \\
\hline 12 & Komunalne usluge, PTT usluge i energenti & $2,00 \%$ & 5,5 \\
\hline 13 & Porezi, takse, naknade & $2,09 \%$ & 5,74 \\
\hline 14 & Ostale usluge i troškovi & $2,07 \%$ & 5,68 \\
\hline 15 & Dobit & $5,00 \%$ & 13,74 \\
\hline & Neto cena bez PDV & $100,00 \%$ & 274,7 \\
\hline & PDV 20\% & & 54,94 \\
\hline & Cena usluge prevoza sa PDV & 329,64 \\
\hline & & & \\
\hline
\end{tabular}

\section{ANALIZA PODATAKA O PREVOZU OPASNIH MATERIJA}

Analiza podataka o prevozu opasnih materija obuhvata detaljnu deskriptivnu statistiku sledećih opasnih materija: dizel gorivo, gazol, ulje za loženje, lako, benzin, smesa gasovitih ugljovodonika, prevedena $u$ tečno stanje, N.D.N. (propan, butan).

Za dalje istraživanje je analizirana opasna materija - dizel gorivo.

Zbog poštovanja zahteva preduzeća da se ne otkriva njihov identitet u ovom master radu biće korišćen termin „,posmatrano preduzeće“. Podaci koji su korišćeni za ovo istraživanje jesu svi podaci bez obzira na prevezenu količinu tereta, broj transportnih jedinica ili broj prevoza na lokaciji između mesta otpreme i mesta dopreme koji su dobijeni od posmatranog preduzeća.

\subsection{Primena deskrptivne statistike na posmatrnani uzorak}

U sledećoj tabeli su prikazane aritmetičke sredine parametara posmatranja po mestima:

Tabela 2. Pregled dobijenih srednjih vrednosti istih parametara po mestima

\begin{tabular}{|c|c|c|c|}
\hline $\begin{array}{c}\text { Srednje } \\
\text { vrednosti }\end{array}$ & $\begin{array}{c}\text { Broj } \\
\text { transportnih } \\
\text { jedinica }\end{array}$ & $\begin{array}{c}\text { Prevezena } \\
\text { količina tereta } \\
\text { u tonama }\end{array}$ & $\begin{array}{c}\text { Broj prevoza } \\
\text { na lokaciji }\end{array}$ \\
\hline Smederevo & 8,43 & 812,39 & 79,83 \\
\hline Pančevo & 6,44 & 1032,01 & 101,74 \\
\hline Novi Sad & 9,79 & 771,46 & 91,25 \\
\hline Niš & 5,55 & 677,78 & 75,89 \\
\hline
\end{tabular}

Dalji rezultati analize deskriptivne statistike jesu testiranje raspodela koje su prikazne u sledećem delu rada. Empirijske raspodele su testirane sa odgovarajućim teorijskim raspodelama verovatnoća. Veličine koje su analizirane odnose se na broj transportnih jedinica, prevezenu količinu tereta i broj prevoza na jednoj lokaciji. Analiza je obuhvatila sve količine koje su prevožene između mesta otpreme - Pančeva, Novog Sada, Niša, Smedereva i svih gradova dopreme tereta.

\subsection{Primena inferencijalne statistike na posmatrnani uzorak}

U svim navedenim analizama, empirijska raspodela koja odgovara u najvećem broju slučajeva jeste eksponencijalna raspodela, kao i na posmatranom pravcu prevoza iz Pančeva. Dva puta se pojavljuje uniformna raspodela (Novi Sad i Niš) kao adekvatna, dok se normalna raspodela pojavljuje samo jednom (Smederevo). U sledećoj tabeli će biti prikazani parametri teorijskih raspodela za izabrane relacije:

Tabela 3. Pregled dobijenih vrednosti parametara teorijskih raspodela po mestima

\begin{tabular}{|c|c|c|c|}
\hline $\begin{array}{l}\text { Srednje } \\
\text { vrednosti }\end{array}$ & $\begin{array}{l}\text { Broj transportnih } \\
\text { jedinica }\end{array}$ & $\begin{array}{c}\text { Prevezena } \\
\text { količina } \\
\text { tereta u } \\
\text { tonama }\end{array}$ & $\begin{array}{c}\text { Broj } \\
\text { prevoza na } \\
\text { lokaciji }\end{array}$ \\
\hline Smederevo & $\square=5.663 ; \rrbracket=8.4306$ & $\lambda=0.00123$ & $\lambda=0.01253$ \\
\hline Pančevo & $\lambda=0.15505$ & $\lambda=0.00635$ & $\lambda=0.02798$ \\
\hline Novi Sad & 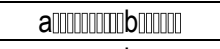 & $\lambda=0.00463$ & $\lambda=0.01382$ \\
\hline Niš & 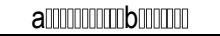 & $\lambda=0.00506$ & $\lambda=0.01546$ \\
\hline
\end{tabular}

\section{ANALIZA TROŠKOVA PREVOZA U DRUM- SKOM SAOBRAĆAJU I REALIZACIJA TOG PREVOZA ŽELEZNIČKIM SAOBRAĆAJEM}

Urađena je analiza prevoza drumskog saobraćaja koji bi potencijalno mogao da se prevozi železnicom. Ispunjeni su svi uslovi da bi se prevoz realizovao železničkim transportom - $\mathrm{u}$ pogledu količine tereta (prevozi se više od 1000 tona), učestalosti prevoza i rastojanja između mesta otpreme i dopreme (više od 90 kilometara). Napravljena je OD (origin-destination) matrica sa najvećim prevozom tereta između prikazanih mesta, a u analizu je pored količine tereta, uključen i broj prevoza na određenoj lokaciji.

Sva mesta otpreme i dopreme su povezana železničkom mrežom u Republici Srbiji. U sledećoj tabeli su prikazani troškovi drumskog prevoza na relaciji Novi Sad Beograd. 
Tabela 4. Prikaz troškova drumskog prevoza na relaciji Novi Sad - Beograd

\begin{tabular}{|c|c|}
\hline \multicolumn{2}{|c|}{ Troškovi drumskog prevoza } \\
\hline \multicolumn{2}{|c|}{ Novi Sad - Beograd } \\
\hline Prevezena količina tereta u tonama & 110755 \\
\hline Broj prevoza na lokaciji & 10439 \\
\hline Broj transportnih jedinica & 36 \\
\hline Rastojanje u km & 94 \\
\hline Cena prevoza po jednoj vožnji (RSD) & 30986 \\
\hline Cena prevoza za sve vožnje (RSD) & 323462854 \\
\hline
\end{tabular}

Iz priloženog se može videti, na osnovu količine prevezenog tereta i rastojanja koje iznosi preko $90 \mathrm{~km}$, tj. ukupne cene prevoza, da bi prevoz dizel goriva u drumskom saobraćaju na relaciji Novi Sad - Beograd bio opravdan da se realizuje železničkim saobraćajem.

Cena drumskog transporta na ostalim relacijama je velika, međutim ne bi bile ostvarene značajne novčane uštede ukliko bi se taj transport realizovao železnicom zbog neelastičnosti železničkog saobraćaja i prilagođavanju disperzivnim zahtevima distribucije.

Benefiti sa aspekta zaštite i uticaja na životnu sredinu nisu utvrđivani u ovom radu.

Kada bi bili izgrađeni lokalni ili regionalni centri za skladištenje robe, možda bi železnički saobraćaj imao značajnu funkciju u prevoženju velikih količina tereta do regionalnih centara koji u čijim bi područjima bile i lokacije koje su prikazane u matricama. Svakako u toj vaijanti treba ispitati i celishodnost formiranja takvih centara.

U ovom radu biće prikazan proračun cene realizacije prevoza železnicom na relaciji Novi Sad - Beograd. Cena prevoza železnicom između ovih mesta otpreme i dopreme.

$$
\begin{gathered}
302,4 \frac{\mathrm{din} .}{\mathrm{kg}} * 1.000 \mathrm{~kg}=302.400 \mathrm{din} . \\
302.400 * 1,2=362.880 \mathrm{din} \\
\frac{110.755 t}{1.600 t}=70 \text { vozova } \\
362.880 * 70=25.401 .600 \mathrm{din} .
\end{gathered}
$$$$
323.462 .854-25.401 .600=298.061 .254 \mathrm{din}
$$

Ukoliko bi se drumski prevoz dizel goriva između Novog Sada i Beograda prebacio na železnicu, ostvarile bi se uštede od 298.061.254 dinara na godišnjem nivou. Ova razlika je sigurno manja od proračunate jer železnički saobraćaj ne može da realizuje u mikrodistribuciju tj. dostava robe drumskim saobraćajem po principu „od vrata do vrata“.

Voz bi išao u proseku svakih 5 dana na relaciji Novi Sad - Beograd.

Sa druge strane, treba imati u vidu da su troškovi prevoza železnicom utvrđeni na osnovu redovnog prevoza. Železnički prevoznici za redovne korisnike daju mogućnost organizacije dogovorenog prevoza.

Obično se dogovorenim prevozom utvrđuju niži prevozni stavovi, što može značiti i niže prevozne troškove. Uzimajući u obzir navedeno može se konstatovati da postoje izuzetne neiskorišćene rezerve u smanjenju troškova prevoza.

\section{ZAKLJUČAK}

Cilj ovog master rada jeste utvrđivanje troškova prevoza u drumskom saobraćaju između određenih mesta otpreme i dopreme, i njihova potencijalna realizacija železničkim saobraćajem kako bi se smanjili troškovi prevoza.

Za ovo istraživanje je analizirana opasna materija - dizel gorivo. Veličine koje su analizirane odnose se na broj transportnih jedinica, prevezenu količinu tereta $\mathrm{i}$ broj prevoza na jednoj lokaciji. Analiza je obuhvatila sve količine koje su prevožene između mesta otpreme - Pančeva, Novog Sada, Niša, Smedereva i svih gradova dopreme tereta. Za opis prevoza teorijskim raspodela korišćena su: eksponecijalna, normalna i uniformna raspodela.

Rezultati inferencijalne statistike jesu da u svim $\mathrm{Na}$ osnovu količine prevezenog tereta i broja prevoza na lokaciji, tj. ukupne cene prevoza, da bi prevoz dizel goriva $u$ drumskom saobraćaju na relaciji Novi Sad - Beograd bio opravdan da se realizuje železničkim saobraćajem. U sledećoj fazi istraživanja bi trebalo utvrditi celishodnost izgradnje regionalnih $\mathrm{i} / \mathrm{ili}$ lokalnih skladišta kako bi ostvarili dodatne uštede.

Veliki su prevozni troškovi drumskog prevoza, a opskrba nekih mesta dizel gorivom zahteva češće dostave, te postavljamo problem uskladištenja date materije.

\section{LITERATURA}

[1] Sremac, S., Arsić. T., Smiljanić, N., Vukobratović, B., Stojić, G., (2017). Safety plans as a prevention in the transport of dangerous goods, ISBN 978-99955-3666-4, str. 97-102, VI International Symposium New Horizons 2017 of Transport and Communications, Doboj, Bosnia and Hercegovina.

[2] Biocanin, R, Ketin, S. Akcidenti u zivotnoj sredini, Internacionalni Univerzitet Travnik, IUT Travnik 2019.

[3] http://www.srbijatransport.rs

[4] Stojić, G., Organizacija železničkog saobraćaja, Fakultet tehničkih nauka, Novi Sad, 2018.

[5] http://srbcargo.rs/sr/tarife

\section{Kratka biografija:}

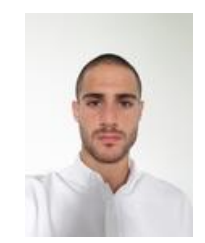

Dragan Smiljanić rođen je u Sremskoj Mitrovici 1996. god. Master rad na Fakultetu tehničkih nauka iz oblasti Saobraćaja odbranio je 2020.god.

kontakt: targija996@gmail.com

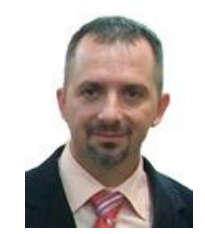

prof. dr Gordan Stojić rođen je u Kumanovu 1971. Doktorirao je na Fakultetu tehničkih nauka 2010. god., a od 2016. je zvanju vanrednog profesora. Oblast interesovanja su orgnazacija i tehnologije transportnih sistema. 